\title{
PROFIL BERPIKIR KREATIF SISWA KELAS AKSELERASI DALAM MEMECAHKAN MASALAH MATEMATIKA TERBUKA
}

\author{
Eni Defitriani \\ Universitas Jambi \\ e.defitrianiz@gmail.com
}

\begin{abstract}
The background of the research is the needs of human resources that are able to think creatively in order to utilize and develop science and technology. One of the ways to overcome it is to optimize the improvement of students' ability to think creatively in accelerated classes. Accelerated classes are accelerated learning program. Thus, the need of creative human resources can be immediately fulfilled. The aim of the research are to determine the students' creativity and describe the process of students' creative thinking in solving open mathematical problem. Creative thinking process is traced by referring to the stage of creative thinking by Wallas, namely preparation, incubation, illumination, and verification. This research is qualitative- descriptive. The research instruments used in the research were a problem-solving task sheet and in-depth interviews. The subjects in this research were students in accelerated classes in Jambi. Analysis of data used data analysis according to Miles and Huberman which consists of data reduction, exposure data and drawing conclusions. The results show that there are $8 \%$ of creative students from 25 students in accelerated class in solving open mathematical problems. Then $72 \%$ are less creative and $20 \%$ are not creative. In solving open mathematical problems, creative and less creative students pass through the four stages of creative thinking process by Wallas. Students who are not creative only pass through the three stages of creative thinking process which are preparation, incubation, and illumination.
\end{abstract}

Keywords: creative thinking, accelerated students

ABSTRAK. Penelitian ini dilatarbelakangi oleh kebutuhan dunia akan sumber daya yang mampu berpikir kreatif agar dapat memanfaatkan dan mengembangkan IPTEK. Salah satu cara untuk mengatasinya adalah mengoptimalkan peningkatan kemampuan berpikir kreatif pada siswa kelas akselerasi. Program kelas akselerasi adalah program percepatan pembelajaran. Sehingga, kebutuhan sumber daya kreatif dapat segera terpenuhi. Tujuan penelitian adalah mengetahui kreativitas siswa dan mendeskripsikan proses berpikir kreatif siswa kelas akselerasi dalam memecahkan masalah matematika terbuka. Proses berpikir kreatif ditelusuri dengan berpedoman pada tahapan berpikir kreatif menurut Wallas, yaitu persiapan, inkubasi, iluminasi, dan verifikasi. Jenis penelitian ini adalah kualitatif-deskriptif. Instrumen penelitian adalah lembar tugas pemecahan masalah dan wawancara secara mendalam. Subjek dalam penelitian ini adalah siswa kelas akselerasi SMP Kota Jambi. Analisis data menggunakan analisis data menurut Miles dan Huberman yaitu reduksi data, pemaparan data dan penarikan kesimpulan. Hasil penelitian menunjukkan bahwa siswa kelas akselerasi dalam memecahkan masalah matematika terbuka dari 25 orang siswa terdapat 8\% siswa kreatif, $72 \%$ kurang kreatif, dan $20 \%$ tidak kreatif. Siswa kelas akselerasi yang kreatif dan kurang kreatif dalam memecahkan masalah matematika terbuka melalui keempat proses berpikir kreatif menurut Wallas. Sedangkan siswa kelas akselerasi yang tidak 
kreatif dalam memecahkan masalah matematika terbuka melalui tiga tahap yaitu persiapan, inkubasi, dan iluminasi.

Kata Kunci: Berpikir kreatif, siswa akselerasi

\section{PENDAHULUAN}

Semakin pesatnya perkembangan IPTEK dewasa ini menyebabkan semakin dibutuhkannya sumber daya yang mampu untuk berpikir kreatif agar dapat memanfaatkan dan mengembangkan IPTEK. Hasil survey The American Society For Training and Development pada para eksekutif dari 93 persen perusahaan yang terdaftar di Fortune 500 menyatakan bahwa kemampuan (soft skill) yang paling menjadi perhatian yang harus dikuasai oleh sumber daya manusianya adalah problem solving (58\%), teamwork (51\%), interpersonal skill (48\%), oral communication (45\%), listening (43\%), writing (41\%), dan goal setting (33\%) (Kusuma, 2011). Kemampuan-kemampuan ini adalah suatu bentuk dari kreativitas. Kemampuan untuk berpikir kreatif atau disebut dengan kreativitas bukanlah suatu bakat yang dibawa sejak lahir dari individu melainkan suatu proses sehingga bisa dipelajari dan diajarkan (Kusuma, 2010).

Matematika adalah ilmu dasar yang memegang peranan penting dalam membentuk dan meningkatkan kemampuan berpikir kreatif seseorang. Hal ini disebabkan karena matematika adalah suatu ilmu pengetahuan yang diajarkan pada setiap jenjang pendidikan dan aplikasinya langsung dapat diterapkan dalam kehidupan sehari-hari. Ini sesuai dengan KTSP Permendiknas Nomor 22 Tahun 2006.

Agar tujuan tersebut dapat terlaksana, peran guru sangatlah penting. Guru merupakan ujung tombak yang berhubungan langsung dengan siswa sebagai subjek dan objek belajar. Bagaimana bagus dan idealnya kurikulum pendidikan, bagaimanapun lengkapnya sarana dan prasarana pendidikan, tanpa diimbangi dengan kemampuan guru dalam mengimplementasikannya, maka semua akan kurang bermakna (Sanjaya, 2007).

Seorang guru harus mempunyai kompetensi pedagogis. Kompetensi pedagogis adalah kemampuan seorang guru dalam pengelolaan pembelajaran 
siswa, salah satunya adalah pemahaman terhadap siswa dan mengembangkan siswa untuk mengaktualisasikan berbagai potensi yang dimilikinya (Sanjaya, 2007). Setiap siswa memiliki karakteristik yang berbeda-beda. Layaknya sidik jari, mereka mempunyai keunikan sendiri. Menurut Uno (2006) karakteristik siswa meliputi bakat, minat, sikap, motivasi belajar, gaya belajar, kemampuan dan proses berpikir, dan kemampuan awal (hasil belajar). Oleh sebab itu, penting bagi guru untuk mengetahui proses berpikir kreatif siswanya. Mengetahui proses berpikir kreatif siswa, akan memudahkan guru untuk merancang pembelajaran. Seperti yang diungkapkan oleh Forsten, Grant, dan Hollas (Kaufelt, 2008) "Bila para siswa tidak belajar dari cara yang kita ajarkan, maka kita perlu mengajar mereka dengan cara yang mereka pelajari”. Selain itu, Sudarman (2009) menyatakan bahwa dengan mengetahui proses berpikir siswa, maka guru dapat melacak letak dan jenis kesalahan yang dilakukan siswa. Kesalahan yang diperbuat siswa dapat dijadikan sumber informasi belajar dan pemahaman bagi siswa.

Berpikir kreatif adalah suatu kombinasi dari berpikir logis dan berpikir divergen, yang mencakup aspek kelancaran, keluwesan, kebaruan, dan keterincian. Untuk mengukur kemampuan berpikir kreatif dapat dilakukan dengan menggunakan soal terbuka (Getzles dan Jackson dalam Mahmudi, 2008). Siswa kelas akselerasi diasumsikan dapat memecahkan masalah matematika yang bersifat terbuka. Hal ini dikarenakan untuk dapat mengikuti program kelas akselerasi harus memenuhi kriteria; Intelegensi Question (IQ) diatas 125, Creativity Question (CQ) dan Task Commitment (TC) yang berada di atas siswa lain pada umumnya.

Berdasarkan latar belakang masalah di atas, rumusan masalah dalam penelitian ini adalah: (1) Bagaimana kreativitas siswa kelas akselerasi dalam memecahkan masalah matematika terbuka? (2) Bagaimana proses berpikir kreatif siswa kelas akselerasi yang kreatif dalam memecahkan masalah matematika terbuka? (3) Bagaimana proses berpikir kreatif siswa kelas akselerasi yang kurang kreatif dalam memecahkan masalah matematika terbuka? dan (4) Bagaimana 
proses berpikir kreatif siswa kelas akselerasi yang tidak kreatif dalam memecahkan masalah matematika terbuka?

Hasil penelitian ini dapat memberikan kegunaan sebagai berikut: (1) Sebagai masukan untuk guru agar dapat mengetahui proses berpikir kreatif siswa. Sehingga guru dapat meningkatkan kreativitas siswa dalam proses pembelajaran; (2) Sebagai sumbangan informasi tentang proses berpikir kreatif siswa kelas akselerasi dalam memecahkan masalah matematika terbuka; (3) Sebagai bahan pertimbangan untuk pengembangan penelitian yang berkaitan dengan proses berpikir kreatif dalam memecahkan masalah matematika terbuka.

\section{METODE PENELITIAN}

Penelitian ini akan mengungkap proses berpikir kreatif siswa dalam memecahkan masalah matematika terbuka, sehingga data yang diperlukan berupa kata-kata lisan dari narasumber. Untuk memperoleh data tersebut, proses pengumpulan data akan dilakukan dengan menggunakan metode wawancara secara mendalam dan penelaahan dokumen. Pada penelitian ini, peneliti bertindak sebagai instrument utama dalam. Data yang telah dikumpulkan dianalisis secara induksi, sehingga proses berpikir kreatif siswa dapat dideskripsikan. Pendeskripsian proses berpikir kreatif siswa akan diinterpretasikan secara apa adanya. Penelitian yang menggambarkan atau mendeskripsikan, dan menginterpretasikan objek secara apa adanya disebut dengan penelitian deskriptif (Best dalam Sukardi, 2003:57). Dengan demikian, penelitian ini digolongkan dalam penelitian kualitatif dengan menggunakan metodologi penelitian kualitatif deskriptif.

\section{Subjek Penelitian}

Subjek dalam penelitian ini adalah tiga orang siswa kelas akselerasi salah satu SMP Negeri di Kota Jambi. Teknik pemilihan subjek adalah teknik purposive sampling. Penelitian ini bertujuan untuk mengungkap proses berpikir kreatif siswa kelas akselerasi dalam memecahkan masalah matematika terbuka, sehingga yang menjadi pertimbangan untuk memilih subjek dalam penelitian ini berdasarkan 
data hasil tugas pemecahan masalah matematika terbuka yang diberikan kepada siswa. Analisis hasil tugas pemecahan masalah menunjukkan kelompok siswa kreatif, kurang kreatif, dan tidak kreatif. Selanjutnya dipilih satu orang dari masing-masing kelompok yang akan diwawancarai secara mendalam untuk mengetahui bagaimana proses berpikir kreatifnya.

\section{Data}

Data yang dikumpulkan dalam penelitian ini adalah data tentang kreativitas siswa kelas akselerasi dalam pemecahan masalah matematika terbuka dan proses berpikir kreatif siswa dalam memecahkan masalah matematika terbuka.

\section{Instrumen Penelitian}

Instrumen utama dalam penelitian ini adalah peneliti sendiri. Sebagai instrumen utama, peneliti berperan sebagai perencana, pelaksana, pengumpul data, penganalisis data, dan akhirnya menjadi pelapor hasil penelitiannya. Instrumen lainnya adalah lembar tugas pemecahan masalah yang digunakan untuk melihat kreativitas siswa dalam memecahkan masalah matematika terbuka dan lembar wawancara yang digunakan untuk mengungkap proses berpikir kreatifnya.

\section{Teknik Pengumpulan Data}

Teknik pengumpulan data dalam penelitian ini dapat dilihat pada Gambar 1.

\section{Kredibilitas Data}

Untuk mempertanggungjawabkan kredibilitas atau kepercayaan terhadap data hasil penelitian ini, peneliti melakukan langkah-langkah berikut: (1) melakukan triangulasi sumber; (2) membuat catatan setiap tahapan penelitian dan dokumentasi yang lengkap; (3) melakukan pentranskripan segera setelah melakukan pengambilan data; dan (4) melakukan pengecekan berulang kali terhadap rekaman suara, lembar jawaban dan transkrip wawancara agar diperoleh hasil yang sahih. 


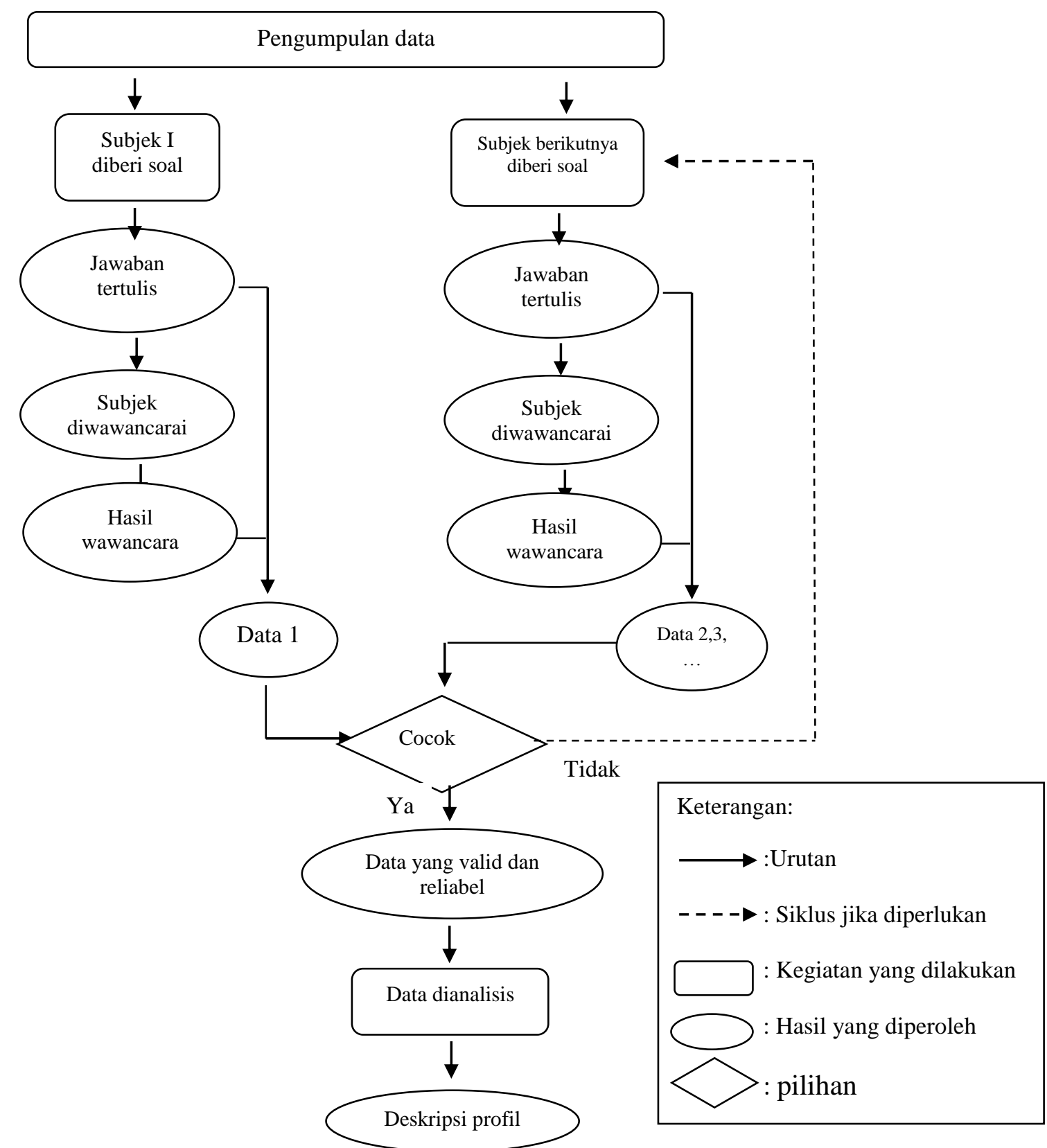

Gambar 1. Diagram teknik pengumpulan data

\section{Analisis Data}

Data hasil tugas pemecahan masalah dianalisis berdasarkan aspek berpikir kreatif, yaitu kelancaran, keluwesan, kebaruan, dan keterincian. Sedangkan data hasil wawancara dianalisis dengan mengacu pada tahapan proses berpikir kreatif menurut Wallas, yaitu persiapan, inkubasi, iluminasi, dan verifikasi. Data hasil wawancara (kualitatif) dalam penelitian ini dianalisis dengan menggunakan teknis 
analisis data model Miles dan Huberman, yaitu: (1) data reduction (reduksi data); (2) data display (pemaparan data/kategorisasi); dan (3) conclusion drawing/verification (penarikan kesimpulan).

\section{HASIL DAN PEMBAHASAN}

Berdasarkan analisis lembar tugas pemecahan masalah matematika terbuka, siswa kelas akselerasi dikelompokkan menjadi tiga tingkatan kreativitas, yaitu kreatif, kurang kreatif, dan tidak kreatif. Berikut disajikan persentase kreativitas siswa kelas akselerasi.

Tabel 1. Persentase Kreativitas Siswa Kelas Akselerasi dalam Memecahkan Masalah Matematika Terbuka

\begin{tabular}{|l|c|c|}
\hline $\begin{array}{c}\text { Kategori } \\
\text { Siswa }\end{array}$ & $\begin{array}{c}\text { Jumlah } \\
\text { Siswa }\end{array}$ & Persentase \\
\hline Kreatif & 2 & $8 \%$ \\
\hline Kurang Kreatif & 18 & $72 \%$ \\
\hline Tidak Kreatif & 5 & $20 \%$ \\
\hline Jumlah & 25 & $100 \%$ \\
\hline
\end{tabular}

Dari tabel di atas dapat disimpulkan bahwa siswa kelas akselerasi dalam memecahkan masalah matematika terbuka kurang kreatif. Berdasarkan hasil wawancara, hal ini dikarenakan siswa tidak terbiasa dengan soal matematika yang bersifat terbuka. Siswa selalu dihadapkan dengan soal-soal rutin yang terdapat dalam buku teks. Menurut Milgram (Munandar, 2009) yang menekankan bahwa intelegensi atau IQ semata-mata tidak dapat meramalkan kreativitas dalam kehidupan nyata. Ini berarti, orang yang memiliki IQ yang tinggi, belum tentu kreatif.

Dari setiap kategori kreativitas siswa, dipilih satu orang yang akan diwawancarai secara mendalam mengenai proses berpikir kreatifnya yang berpedoman pada proses berpikir kreatif menurut Wallas. Berikut disajikan secara rinci pada tabel di bawah ini. 
Tabel 2. Proses Berpikir Kreatif Siswa Kelas Akselerasi Berdasarkan Kategori Kreativitas Siswa

\begin{tabular}{|c|c|c|c|}
\hline \multirow{2}{*}{$\begin{array}{l}\text { Tahap Berpikir } \\
\text { Kreatif Wallas }\end{array}$} & \multicolumn{3}{|c|}{ Tingkatan Kreativitas } \\
\hline & Kreatif & Kurang Kreatif & Tidak Kreatif \\
\hline Persiapan & $\begin{array}{l}\text { - Siswa memahami } \\
\text { maksud soal } \\
\text { - Siswa berusaha } \\
\text { untuk } \\
\text { mengumpulkan } \\
\text { informasi dan } \\
\text { mengaitkannya } \\
\text { dengan pengetahuan } \\
\text { prasyarat }\end{array}$ & $\begin{array}{l}\text { - Siswa mencoba } \\
\text { memahami masalah } \\
\text { - Siswa mengumpulkan } \\
\text { informasi dari soal dan } \\
\text { mengaitkannya dengan } \\
\text { pengetahuan prasyarat. } \\
\text { Namun tidak dapat } \\
\text { menyebutkan } \\
\text { pengetahuan prasyarat } \\
\text { apa yang dibutuhkan } \\
\text { untuk memecahkan } \\
\text { masalah }\end{array}$ & $\begin{array}{l}\text { - Siswa tidak dapat } \\
\text { memahami maksud } \\
\text { soal dengan baik } \\
\text { - Siswa berusaha } \\
\text { mengumpulkan } \\
\text { informasi dan } \\
\text { mengaitkannya } \\
\text { dengan pengetahuan } \\
\text { prasyarat namun } \\
\text { informasi yang } \\
\text { dikumpulkan tidak } \\
\text { relevan } \\
\end{array}$ \\
\hline Inkubasi & $\begin{array}{l}\text { - Siswa berhenti } \\
\text { sejenak untuk } \\
\text { membaca dan } \\
\text { memahami soal yang } \\
\text { diberikan serta } \\
\text { berpikir untuk } \\
\text { menemukan solusi } \\
\text { soal }\end{array}$ & $\begin{array}{l}\text { - Siswa berhenti sejenak } \\
\text { ketika menemukan } \\
\text { kesulitan } \\
\text { - Kegiatan yang dilakukan } \\
\text { ketika berhenti sejenak } \\
\text { adalah memikirkan } \\
\text { solusi dari masalah yang } \\
\text { dihadapi }\end{array}$ & $\begin{array}{l}\text { - Siswa berhenti } \\
\text { sejenak untuk } \\
\text { memikirkan solusi } \\
\text { dari pemecahan } \\
\text { masalah tersebut }\end{array}$ \\
\hline Iluminasi & $\begin{array}{l}\text { - Siswa dapat } \\
\text { menemukan banyak } \\
\text { jawaban dari solusi } \\
\text { pemecahan masalah. } \\
\text { Ini menunjukkan dia } \\
\text { memenuhi aspek } \\
\text { berpikir kreatif yaitu } \\
\text { kelancaran, } \\
\text { keluwesan, } \\
\text { kebaruan, dan } \\
\text { kerincian }\end{array}$ & $\begin{array}{l}\text { - Siswa menemukan } \\
\text { jawaban lebih dari satu. } \\
\text { - Aspek berpikir kreatif } \\
\text { yang ditemui adalah } \\
\text { kelancaran, keluwesan, } \\
\text { dan kerincian. } \\
\text { Sedangkan kebaruan } \\
\text { tidak ditemukan }\end{array}$ & $\begin{array}{l}\text { - Siswa menemukan } \\
\text { banyak solusi dari } \\
\text { pemecahan masalah, } \\
\text { namun solusi yang } \\
\text { diberikan tidak } \\
\text { sesuai dengan } \\
\text { harapan peneliti. } \\
\text { Jawaban yang } \\
\text { diberikan oleh siswa } \\
\text { sesuai dengan } \\
\text { pemahaman siswa } \\
\text { terhadap soal yang } \\
\text { diberikan }\end{array}$ \\
\hline Verifikasi & $\begin{array}{l}\text { - Siswa mengecek } \\
\text { kembali jawabannya } \\
\text { karena takut ada } \\
\text { kekeliruan dalam } \\
\text { jawabannya }\end{array}$ & $\begin{array}{l}\text { - Siswa memeriksa } \\
\text { kembali jawaban yang } \\
\text { diperolehnya }\end{array}$ & $\begin{array}{l}\text { - Siswa tidak } \\
\text { mengecek kembali } \\
\text { jawabannya. }\end{array}$ \\
\hline
\end{tabular}

Berdasarkan hasil penelitian yang telah dipaparkan pada tabel di atas, siswa kelas akselerasi dengan kategori kreatif, proses berpikir pada tahap persiapan sesuai dengan teori hipotetik yang disusun oleh Siswono (2004), bahwa siswa yang berada pada tingkat kreatif adalah siswa yang mampu menunjukkan 
pemahaman terhadap tugas yang diberikan dan mampu membangun atau membangkitkan ide-ide dari materi yang sudah dipelajari. Pada tahap inkubasi siswa berhenti sejenak. Hasil dari tahap ini akan dilihat pada tahap iluminasi. Pada tahap iluminasi ini siswa dapat menemukan lebih dari satu jawaban. Jawaban yang diberikan oleh siswa kreatif ini mengandung suatu kebaruan, jika dibandingkan dengan jawaban siswa lainnya. Ini merupakan hasil dari proses berpikir yang dilakukan pada tahap sebelumnya, yaitu tahap inkubasi. Hal ini sejalan dengan pendapat Munandar (2009) bahwa tahap iluminasi adalah tahap timbulnya insight, saat timbulnya inspirasi dan gagasan baru. Siswa kreatif juga mengalami tahap verifikasi. Hal ini sejalan dengan teori hipotetik yang disusun oleh Siswono (2004) menyatakan bahwa siswa kreatif melakukan perbaikanperbaikan untuk mendapatkan jawaban tugas yang sesuai dengan permintaan. Ini dibuktikan dari jawaban yang diberikan oleh siswa. Semua jawaban yang diberikan benar dan memenuhi semua aspek berpikir kreatif, yaitu kelancaran, keluwesan, kebaruan, dan kerincian.

Berdasarkan hasil penelitian tahapan berpikir siswa kelas akselerasi yang kurang kreatif, proses berpikir pada tahap persiapan sesuai dengan teori hipotetik yang disusun oleh Siswono (2004) menyatakan bahwa siswa yang berada pada tingkat kurang kreatif adalah siswa yang mampu menunjukkan pemahaman terhadap tugas yang diberikan tetapi hasil tugas siswa tidak memenuhi semua kriteria produk kreativitas. Hal ini terlihat dari jawaban siswa yang tidak mengandung unsur kebaruan dalam jawaban yang diberikannya. Pada tahap inkubasi, individu seakan-akan melepaskan diri untuk sementara dari masalah yang dihadapinya, dalam arti seseorang tersebut tidak memikirkan masalahnya secara sadar, tetapi "mengeramnya" dalam alam bawah sadar (Munandar, 2009). Siswa kurang kreatif tidak mencoba untuk melepaskan diri dari masalah yang sedang dihadapi, namun mencoba untuk memikirkan solusi dari masalah yang dihadapi. Hal ini sesuai dengan teori hipotetik yang disusun oleh Siswono (2004) menyatakan bahwa siswa kurang kreatif hanya membangkitkan ide dari materi matematika yang sudah dipelajari. Ini dapat dilihat pada tahap iluminasi, yang merupakan hasil dari tahap inkubasi. Pada tahap iluminasi, hasil penelitian 
menunjukkan bawah siswa dapat menemukan lebih dari satu jawaban. Semua jawaban siswa merupakan hasil pemikiran hanya dari soal yang disajikan. Siswa tidak dapat menemukan jawaban yang mengandung aspek kebaruan. Hal ini sejalan dengan teori hipotetik yang disusun oleh Siswono (2004), yang menyatakan bahwa siswa kurang kreatif dalam memecahkan masalah matematika terbuka memberikan jawaban yang tidak memenuhi semua kriteria produk kreatif. Siswa kurang kreatif melakukan tahap verifikasi. Siswa mengecek kembali jawaban yang telah dikerjakan. Berdasarkan teori hipotetik yang disusun oleh Siswono (2004) menyatakan bahwa siswa kurang kreatif belum dapat melakukan perbaikan untuk menjawab tugas yang sesuai dengan permintaan. Hal ini ditunjukkan dari jawaban siswa yang tidak memberikan jawaban sesuai dengan permintaan soal, padahal siswa dapat memahami maksud soal dan apa yang ditanyakan dari soal dengan baik.

Pada siswa tidak kreatif, hasil penelitian menunjukkan bahwa siswa berusaha untuk memahami masalah yang dihadapainya, namun pemahamannya kurang tepat. Siswa juga menentukan informasi yang relevan dan mengaitkannya dengan pengetahuan prasyarat yang dikuasainya untuk memecahkan masalah matematika terbuka sesuai dengan pemahaman siswa terhadap maksud soal. Hal ini sejalan dengan teori hipotetik yang disusun oleh Siswono (2004) menyatakan bahwa siswa tidak kreatif belum bisa menunjukkan pemahaman terhadap tugas yang diberikan. Pada tahap inkubasi, siswa berhenti sejenak. Kegiatan yang dilakukan ketika berhenti sejenak adalah berpikir mencari solusi dari masalah yang dihadapi. Solusi dari masalah yang dipikirkan adalah yang sesuai dengan hasil pemahaman siswa terhadap maksud soal yang diberikan. Hasil pada tahap ini dapat dilihat pada tahap iluminasi. Pada tahap iluminasi siswa dapat menemukan lebih dari satu jawaban. Namun tidak memenuhi semua kriteria produk kreativitas (Siswono, 2004). Sedangkan siswa tidak kreatif tidak melalui tahap verifikasi. Ini menunjukkan bahwa siswa tidak mempu untuk berpikir kreatif. Hal ini sejalan dengan teori hipotetik yang disusun oleh Siswono (2004), yang menyatakan bahwa siswa kurang kreatif tidak menunjukkan proses berpikir kreatif (hanya sekedar mengulang atau recall). 


\section{KESIMPULAN DAN SARAN}

Berdasarkan hasil penelitian dapat disimpulkan bahwa: (1) Dalam memecahkan masalah matematika terbuka, dari 25 orang siswa kelas akselerasi terdapat sebanyak $8 \%$ siswa kreatif, $72 \%$ kurang kreatif, dan $20 \%$ tidak kreatif; (2) Siswa kelas akselerasi yang kreatif dalam memecahkan masalah matematika terbuka melalui keempat tahapan proses berpikir kreatif menurut Wallas dan memenuhi keempat aspek berpikir kreatif; (3) Siswa kelas akselerasi yang kurang kreatif dalam memecahkan masalah matematika terbuka melalui keempat tahapan proses berpikir kreatif menurut Wallas dan hanya memenuhi tiga aspek berpikir kreatif, yaitu kelancaran, keluwesan, dan kerincian; dan (4) Siswa kelas akselerasi yang tidak kreatif dalam memecahkan masalah matematika terbuka hanya melalui tiga tahap proses berpikir kreatif menurut Wallas, yaitu persiapan, inkubasi, dan iluminasi serta tidak memenuhi aspek berpikir kreatif.

Saran-saran yang dapat diberikan berdasarkan hasil penelitian adalah: (1) Guru diharapkan dapat menggunakan soal-soal matematika yang bersifat terbuka untuk meningkatkan kemampuan berpikir kreatif siswa; (2) Siswa kelas akselerasi yang kreatif dan kurang kreatif hendaknya lebih sering diberikan soal-soal terbuka, agar siswa dapat terus melatih dan meningkatkan pemikiran kreatifnya dalam memecahkan masalah; (3) Siswa kelas akselerasi yang tidak kreatif dalam memecahkan soal terbuka hendaknya lebih diberikan perhatian pada saat pemahaman maksud soal, agar siswa dapat menyelesaikan soal dengan benar; (4) Penelitian ini diharapkan dapat menjadi gambaran untuk penelitian selanjutnya mengenai proses berpikir kreatif siswa dalam memecahkan masalah matematika terbuka; (5) Untuk penelitian selanjutnya dapat dikembangkan materi yang lebih bervariasi, agar siswa lebih semangat dan termotivasi untuk menggali ide-ide kreatif dalam menemukan alternatif jawaban.

\section{UCAPAN TERIMA KASIH}

Penulis mengucapkan terima kasih yang sebesar-besarnya kepada semua pihak yang telah membantu dalam penyusunan dan pelaksanaan penelitian ini. 
Terutama kepada Bapak Dr. Kamid, M.Si dan Ibu Dra. Sofnidar, M.Si yang telah memberikan bimbingan dan sarannya.

\section{DAFTAR PUSTAKA}

Kaufelt, Martha. 2008. Wahai Para Guru, Ubahlah Cara Mengajarmu!. Jakarta: PT. Indeks

Mahmudi, Ali. 2008. Mengembangkan Soal Terbuka (Open Ended Problem) Dalam Pembelajaran Matematika. Makalah Disampaikan Pada Seminar Nasional Matematika dan Pendidikan Matematika yang Diselenggarakan oleh Jurusan Pendidikan Matematika FMIPA UNY Yogyakarta pada hari Jumat, 28 November 2008, (Online), (http://Makalah02PIPM2008 MengembangkanSoalTerbuka_.pdf, diakses 7 Oktober 2011)

Munandar, Utami. 2009. Pengembangan Kreativitas Anak Berbakat. Jakarta: Rineka Cipta

Sanjaya, Wina. 2007. Strategi Pembelajaran Berorientasi Standar Proses Pendidikan. Jakarta: Kencana

Siswono. 2004. Identifikasi Proses Berpikir Kreatif Siswa dalam Pengajuan Masalah (Problem Posing) Matematika Berpandu dengan Model Wallas dan Creative Problem Solving $(C P S)^{I}$. Buletin Pendidikan Matematika Volume 6 Nomor 2, Oktober 2004, (Online), (http://paper04wallascps1 tatagyes.files.wordpress.com, diakses pada 12 September 2011)

Sudarman. 2009. Proses Berpikir Siswa Climber dalam Menyelesaikan Masalah Matematika, (Online), (http://1010919.pdf, diakses 4 November 2011)

Sugiyono. 2007. Memahami Penelitian Kualitatif. Bandung: Alfabeta

Sukardi. 2003. Metedologi Penelitian Pendidikan. Jakarta: Bumi Aksara

Uno, Hamzah. 2006. Perencanaan Pembelajaran. Jakarta:PT. Bumi Aksara 